\title{
Stroke occurring in patients with cognitive impairment or dementia
}

\author{
Comprometimento cognitivo prévio ou demência em pacientes com acidente \\ vascular cerebral
}

Solène Moulin ${ }^{1}$, Didier Leys ${ }^{1}$

\begin{abstract}
One in six patients admitted for stroke was previously demented. These patients have less access to appropriate stroke care, although little is known about their optimal management. Objective:To determine how pre-stroke cognitive impairment can be detected, its mechanism, and influence on outcome and management. Methods: Literature search. Results: (i) A systematic approach with the Informant Questionnaire of Cognitive Decline in the Elderly is recommended; (ii) Pre-stroke cognitive impairment may be due to brain lesions of vascular, degenerative, or mixed origin; (iii) Patients with pre-stroke dementia, have worse outcomes, more seizures, delirium, and depression, and higher mortality rates; they often need to be institutionalised after their stroke; (iv) Although the safety profile of treatment is not as good as that of cognitively normal patients, the risk: benefit ratio is in favour of treating these patients like others. Conclusion: Patients with cognitive impairment who develop a stroke have worse outcomes, but should be treated like others.
\end{abstract}

Keywords: stroke; cerebral infarction; cerebral hemorrhage; dementia; mild cognitive impairment.

\section{RESUMO}

Um em cada seis pacientes internados em decorrência de acidente vascular cerebral (AVC) apresenta diagnóstico prévio de demência. Estes indivíduos têm menor acesso à assistência recomendada para pacientes com AVC, mas pouco ainda se sabe em relação aos cuidados médicos ideais que devem receber. Objetivo: Determinar como o comprometimento cognitivo prévio ao AVC pode ser detectado, qual o mecanismo etiológico subjacente, e as consequências para o prognóstico e para o acompanhamento clínico. Método: Pesquisa bibliográfica. Resultados: (i) O rastreamento sistemático com o Informant Questionnaire of Cognitive Decline in the Elderly é recomendado; (ii) O comprometimento cognitivo preexistente pode ser devido a lesões cerebrais de origem vascular, degenerativa ou mista; (iii) Pacientes com demência prévia ao AVC têm pior prognóstico, maior frequência de crises epilépticas, de delirium e depressão, além de taxas de mortalidade mais altas; eles frequentemente são institucionalizados após o AVC; (iv) Embora a tolerabilidade às medicações não seja tão boa quanto a de pacientes com AVC sem comprometimento cognitivo, a relação risco/benefício é a favor de tratamento similar àquele oferecido aos demais pacientes. Conclusão: Pacientes com comprometimento cognitivo que apresentam AVC têm pior prognóstico, porém eles devem ser tratados de modo semelhante aos demais casos.

Palavras-chave: acidente vascular cerebral; infarto cerebral; hemorragia cerebral; demência; comprometimento cognitivo leve.

Stroke survivors are at risk for (i) new vascular events such as recurrent stroke ${ }^{1}$, myocardial infarction ${ }^{2}$ or vascular death $^{3}$; (ii) complications of treatments'; and (iii) delayed neurological complications, such as epileptic seizures ${ }^{5,6}$, cognitive impairment ${ }^{7.8}$, depression ${ }^{9}$, and pain ${ }^{10}$. Cognitive impairment is one of the major causes of dependency after stroke $e^{7,8}$.

It is quite frequent that cognitive impairment, or even dementia, was already present before the stroke $e^{7,8}$. Stroke and cognitive impairment are both common, occur in the same age category, and share similar risk factors ${ }^{11}$. Moreover, stroke lesions can lead to cognitive impairment, alone or in association with Alzheimer pathology ${ }^{11}$. Most studies on the relationship between stroke and cognitive impairment have focused on cognitive impairment occurring after stroke, or on patients with cognitive impairment who have "apparently silent" brain lesions of vascular origin. However, although one patient in six admitted for a stroke was already demented before the stroke ${ }^{7,12,13,14}$, and probably many more were cognitively impaired, little is known about the characteristics of stroke occurring in patients with pre-existing cognitive decline, and about the optimal management of stroke in these patients.

1 Université de Lille. INSERM U 1171, Troubles cognitifs dégénératifs et vasculaires. CHU de Lille, Service de Neurologie, Lille, France.

Correspondence: Didier Leys; Univ. Lille, INSERM U 1171, Degenerative \& Vascular Cognitive Disorders, CHU Lille, Department of Neurology, F-59000 Lille, France; E-mail: didier.leys@univ-lille2.fr

Conflict of interest: There is no conflict of interest to declare.

Support: University Lille 2, CHU Lille, INSERM.

Received 18 September 2016; Accepted 10 October 2016. 
The objectives of this review were to determine how pre-existing cognitive impairment in stroke patients can be detected, what their mechanisms are, and what their possible influence on outcome and management are.

\section{HOW TO DETECT PRE-EXISTING COGNITIVE IMPAIRMENT IN PATIENTS ADMITTED FOR STROKE?}

As stroke lesions may induce neuropsychological deficits, it may be difficult to determine whether or not the patient was demented before the stroke by an assessment of the patient in the stroke unit: cognitive deficits detected after stroke onset may be due to brain lesions related to the stroke, and were not present before the stroke ${ }^{8}$. Therefore, another strategy is needed. The global clinical impression based on the clinical judgement of the physician after an interview with relatives or with the general practitioner provides some information ${ }^{15}$, but the reliability between and within physicians is poor. A systematic approach with the Informant Questionnaire of Cognitive Decline in the Elderly (IQCODE) ${ }^{16}$ provides more reliable and reproducible results. In the original version, this questionnaire consisted of 26 questions regarding changes experienced by the patient over the last 10 years in various aspects of daily behaviour that require memory and other intellectual abilities $^{16}$. A close relative is interviewed and the participation of the patient is not required. The IQCODE can, therefore, be used when the neuropsychological evaluation is possibly influenced by stroke, or is not feasible because of coma or severe aphasia. A short version of IQCODE is now available, with the 16 most relevant questions of the old version ${ }^{17}$, and has been validated in several languages.

Patients can be classified as previously demented when they have an IQCODE score of 104 or more (long version) $)^{16}$ or 64 or more (short version) ${ }^{17}$, and cognitively normal when they have an IQCODE score of 78 (long version) ${ }^{16}$ or 64 (short version $)^{17}$. The results at the IQCODE have an excellent correlation with those of the Mini-Mental State Examination (MMSE) when tested in the community ${ }^{18}$. The limitations of the IQCODE are the need for a reliable informant who meets with the patient at least once a week, and it to be used within 48 hours after admission to prevent any influence on the relative by the current status of the patient ${ }^{18}$. These limitations explain why the IQCODE cannot be used in approximately $20 \%$ of patients ${ }^{12}$. Another limitation is that the IQCODE is time-consuming.

\section{How frequent is pre-existing cognitive impairment in stroke?}

Pre-existing dementia, defined as an IQCODE score of 104 (long version) or 64 (short version) or higher, has been reported with a frequency of $14.4 \%$ (95\%CI $12.0 \%$ to $16.8 \%$ ) in hospital-based studies and $9.2 \%$ (95\%CI $6.9 \%$ to $11.3 \%)$ in population-based studies ${ }^{7}$. The frequency of pre-stroke cognitive impairment with no dementia (CIND) is more difficult to evaluate routinely, but seems to be much higher ${ }^{19,20}$.

\section{Mechanisms of pre-existing cognitive impairment}

Pre-existing cognitive impairment is due to the presence of brain lesions before stroke, that can be of vascular, or degenerative origin, or both ${ }^{21}$.

Various types of pre-existing brain lesions of vascular origin are frequently found in patients with pre-existing dementia, but they have not been systematically evaluated in large series of patients with pre-stroke CIND. These pre-existing brain lesions consist of:

1) Previous strokes of any severity or type, found to be associated with pre-existing dementia in a pooled analysis of six studies ${ }^{7}$ : OR 2.2 (95\%CI 1.6 to 3.0 ).

2) Silent infarcts are infarcts identified on the baseline computed tomographic (CT) or magnetic resonance imaging (MRI) scan performed on admission, in the absence of any clinical history of stroke or transient ischaemic attack that could be explained by the lesion on admission. They are present in approximately $20 \%$ of patients admitted for acute stroke who underwent a CT $\mathrm{scan}^{22}$, and more in those who underwent a MRI scan. In the two studies of consecutive patients with stroke, where the presence of silent infarcts was evaluated, silent infarcts were present in 21 of $72(29.2 \%)$ patients with pre-existing dementia and 98 of 334 (29.4\%) without, suggesting no statistical relationship, with a large area of uncertainty (odds ratio [OR] 1.00; $95 \%$ CI 0.4 to $2.4^{7}$.

3) White matter changes are more frequent in patients who have pre-existing cognitive impairment (54 of 100 in patients with dementia vs. 187 of 672 in patients without, OR: 2.8 ; $95 \%$ CI: 1.4-5.6 $)^{7}$. Depending on the age of subjects, and imaging technique used, they can also be found on CT or MRI scans of normal subjects ${ }^{23}$. However, at the community level, those who have white matter changes have a 1.9 fold increased risk (95\% CI 1.3-2.8) of becoming demented ${ }^{23}$. In patients with mild cognitive impairment, patients with white matter changes are more likely to decline ${ }^{24}$ or become demented ${ }^{25}$, with a dose effect relationship. These abnormalities are more frequent in subjects with vascular risk factors, especially arterial hypertension, and previous strokes, especially in association with small-vessel disease, such as lacunar infarcts and deep spontaneous intracerebral haemorrhages. In stroke patients, these are independently associated with an increased risk of post stroke dementia, recurrent stroke and myocardial infarction ${ }^{23}$.

4) Brain microbleeds have not specifically been studied in the context of pre-existing dementia. However, they are more frequent in patients with recurrent strokes, intra-cerebral haemorrhages, and dementia, but a causal relationship is not certain ${ }^{26}$. They may be just a marker of the underlying pathology that can be the cause of dementia, especially in patients with lobar haemorrhages ${ }^{21}$. 
5) Brain atrophy present before stroke is frequent in patients with pre-existing dementia. Medial temporal lobe atrophy is significantly more frequent in patients with pre-stroke dementia (OR 7.7; 95\%CI 4.3 to 13.8). Atrophy is usually considered as a marker of Alzheimer's disease ${ }^{27}$, although it has been also reported as the consequence of pure vascular lesions ${ }^{28}$. There is actual evidence that global brain atrophy ${ }^{29,30}$ and medial temporal lobe atrophy can also be the consequence of pure vascular disorders ${ }^{28}$.

\section{Influence of pre-existing cognitive impairment on stroke outcome}

Patients who have pre-existing cognitive impairment or dementia, have an overall worse outcome compared to patients who were cognitively normal before stroke. They are more likely, at the acute stage, to develop seizures ${ }^{5}$, and delirium, especially in cases of co-existent infection or metabolic disorder ${ }^{31}$, or to die $^{32}$. After three years, they are more likely to $\mathrm{die}^{32}$, or to develop depressive symptoms ${ }^{33}$. Patients with CIND are more likely to be institutionalised after a stroke ${ }^{34}$.

\section{Acute stroke management in patients with pre-existing cognitive impairment}

\section{Stroke unit care}

Although stroke unit care is highly recommended for all stroke patients ${ }^{35}$ without exception, patients with pre-existing cognitive impairment tend to be less frequently admitted to stroke unit ${ }^{36}$. Pre-existing cognitive functioning was not considered in stroke unit trials, and some of them even excluded patients with clearly identified pre-existing dementia. There is no rationale to exclude these patients from stroke unit care, provided they are not considered at a stage of purely palliative care.

\section{Intravenous recombinant tissue plasminogen activator (rt-PA)}

The license of intravenous recombinant tissue plasminogen activator (rt-PA) in the European Union is restricted to patients aged 80 years or less in many countries, but most centres do not follow this rule anymore ${ }^{37}$. According to the results from the $3^{\text {rd }}$ International Stroke Trial ${ }^{38}$ and the updated meta-analysis ${ }^{39}$ that proved the efficacy of rt-PA in patients aged 80 years or more, the use of rt-PA for elderly patients in clinical practice has increased. Therefore, more ischaemic stroke patients with cognitive impairment are eligible for thrombolysis ${ }^{40}$. However, the safety and the efficacy of rt-PA for these patients are controversial. These patients often have underlying brain pathology, such as leukoaraiosis, brain microbleeds, multiple micro-infarcts as the consequence of cerebral amyloid angiopathy ${ }^{41}$ or lipohyalinosis ${ }^{42}$. Leukoaraiosis has been reported as a risk for haemorrhagic transformation after rt-PA ${ }^{43}$. Cerebral microbleeds ${ }^{44}$ and small-vessel disease ${ }^{45}$ are also markers of increased risks for haemorrhagic transformation. However other studies have shown that this effect is modest and should not prevent the administration of rt-PA ${ }^{46}$. Theoretically, patients with pre-stroke cognitive impairment may have a higher sensitivity to the toxic effect of rt-PA and a lower capacity to recover from brain injury ${ }^{47}$. Despite these theoretical reasons for the reduced efficacy of rt-PA and worse safety profiles, no study has found an increased rate of haemorrhagic transformation after intravenous rt-PA in patients with pre-stroke cognitive impairment ${ }^{19,20,48,49,50}$.

\section{Other acute stroke treatments}

Other treatments validated at the acute stage of stroke, such as mechanical thrombectomy and aspirin, have not been evaluated in patients with pre-stroke cognitive impairment. Decompressive surgery is not really a matter of interest here because it is performed in patients who are usually too young to be severely cognitively impaired before stroke.

\section{Secondary stroke prevention in patients with pre-existing cognitive impairment}

\section{Management of vascular risk factors}

At the chronic phase of stroke, arterial hypertension should be treated as a common risk factor for recurrence of stroke, myocardial infarction and cognitive impairment. Regarding stroke prevention, the lower blood pressure the better $^{51}$. The positive effect of antihypertensive therapy on cognitive function has been reported in several studies in primary prevention trials and in a secondary prevention trial.

The benefit of diabetes medication on the prevention for cognitive decline is still debated and there is no specific data on patients who have a stroke.

Systematic reviews found no deleterious effect of statins on the risks of intracerebral haemorrhage in the primary and secondary prevention for vascular disease ${ }^{52}$.

\section{Aspirin}

No study has evaluated the safety and efficacy of aspirin to prevent recurrence of ischaemic stroke in patients with cognitive impairment. We need additional investigation to test the safety of aspirin in secondary prevention of stroke among post stroke cognitively impaired patients.

\section{Oral anticoagulant}

Anticoagulation is an established treatment in patients with atrial fibrillation for the primary and secondary prevention of ischaemic stroke. It is reported that atrial fibrillation patients with cognitive impairment are sometimes not treated with anticoagulation although there is no clear contraindication $^{53}$. A subgroup analysis of 2,510 patients with atrial fibrillation enrolled in the ACTIVE-W showed that a low score on the MMSE was related to a short time-in-therapeutic-range and caused more vascular events and bleeding ${ }^{54}$. Yet the rate of vascular event and bleeding were no longer different after adjustment of time-in-therapeutic-range. On the contrary, 
another study revealed that mild to moderate cognitive impairment did not require more time to achieve therapeutic anticoagulation, or decreased anticoagulation stability, or extra intensive clinic management versus patients with normal cognition ${ }^{54}$. This could depend on the environmental controls of the patients.

The equivalent efficacy for preventing ischaemic stroke and the lower risk for cerebral haemorrhage with new oral anticoagulants are clear advantages in patients with cognitive impairment, but they have not specifically been evaluated.

\section{Carotid endarterectomy}

Carotid endarterectomy (CEA) is recommended for selected patients with symptomatic and asymptomatic carotid stenosis for the prevention of first and recurrent stroke ${ }^{35}$. The impact of CEA on the preoperative cognitive function remains debatable, and no study has evaluated the risk:benefit ratio of CEA between cognitive change, functional outcome and incidence of future stroke. Therefore, performing CEA for the purpose of treating cognitive impairment is not recommended today; however, there is no reason not to perform CEA when indicated because of preoperative cognitive dysfunction. In future CEA trials, evaluation of the influence of preoperative cognitive function on the outcome and postoperative cognitive function should be included as an outcome measure.

In conclusion, patients with cognitive impairment who develop a stroke have worse outcomes, both at the acute stage and during the follow up, with more dependency and increased mortality. There is no reason not to treat these patients with the best therapeutic strategy at the acute stage (stroke unit care in all patients, thrombolysis and/or thrombectomy in eligible ischaemic stroke patients, aspirin in patients not eligible for recanalization procedures or after 24 hours), and for secondary prevention (optimal management of risk factors in all, antithrombotic in ischaemic stroke patients - oral anticoagulant in cardiopathies, aspirin, and carotid surgery when appropriate. Although the safety profile of different therapeutic strategies is not as good as that of cognitively normal patients, the risk:benefit ratio is in favour of treating these patients like others in most cases.

\section{References}

1. Mas JL, Zuber M. Recurrent cerebrovascular events in patients with patent foramen ovale, atrial septal aneurysm, or both and cryptogenic stroke or transient ischemic attack. French Study Group on Patent Foramen Ovale and Atrial Septal Aneurysm. Am Heart J. 1995;130(5):1083-8. http://doi.org/10.1016/0002-8703(95)90212-0

2. Rohweder G, Ellekjær H, Salvesen $\emptyset$, Naalsund E, Indredavik B. Functional outcome after common poststroke complications occurring in the first 90 days. Stroke. 2015;46(1):65-70. http://doi.org/10.1161/STROKEAHA.114.006667

3. Hartmann A, Rundek T, Mast H, Paik MC, Boden-Albala B, Mohr JP et al. Mortality and causes of death after first ischemic stroke: the Northern Manhattan Stroke Study. Neurology. 2001;57(11):2000-5. http://doi.org/10.1212/WNL.57.11.2000

4. Steiner T, Rosand J, Diringer M. Intracerebral hemorrhage associated with oral anticoagulant therapy: current practices and unresolved questions. Stroke. 2006;37(1):256-62. http://doi.org/10.1161/01.STR.0000196989.09900.f8

5. Cordonnier C, Hénon H, Derambure P, Pasquier F, Leys D. Influence of pre-existing dementia on the risk of post-stroke epileptic seizures. J Neurol Neurosurg Psychiatry. 2005;76(12):1649-53. http://doi.org/10.1136/jnnp.2005.064535

6. Rossi C, De Herdt V, Dequatre-Ponchelle N, Hénon H, Leys D, Cordonnier $\mathrm{C}$ et al. Incidence and predictors of late seizures in intracerebral hemorrhages. Stroke. 2013;44(6):1723-5. http://doi.org/10.1161/STROKEAHA.111.000232

7. Pendlebury ST, Rothwell PM. Prevalence, incidence, and factors associated with pre-stroke and post-stroke dementia: a systematic review and meta-analysis. Lancet Neurol. 2009;8(11):1006-18. http://doi.org/10.1016/S1474-4422(09)70236-4

8. Leys D, Hénon H, Mackowiak-Cordoliani MAA, Pasquier F. Poststroke dementia. Lancet Neurol. 2005;4(11):752-9. http://doi.org/10.1016/S1474-4422(05)70221-0

9. Hackett ML, Yapa C, Parag V, Anderson CS. Frequency of depression after stroke: a systematic review of observational studies. Stroke. 2005;36(6):1330-40. http://doi.org/10.1161/01.STR.0000165928.19135.35

10. Jönsson AC, Delavaran H, Iwarsson S, Ståhl A, Norrving B, Lindgren A. Functional status and patient-reported outcome 10 years after stroke: the Lund Stroke Register. Stroke. 2014;45(6):1784-90. http://doi.org/ 10.1161/STROKEAHA.114.005164

11. Pasquier F, Leys D. Why are stroke patients prone to develop dementia? J Neurol. 1997;244(3):135-42. http://doi.org/10.1007/s004150050064

12. Hénon H, Pasquier F, Durieu I, Godefroy O, Lucas C, Lebert F et al. Preexisting dementia in stroke patients. Baseline frequency, associated factors, and outcome. Stroke. 1997;28(12):2429-36. http://doi.org/10.1161/01.STR.28.12.2429

13. Barba R, Castro MD, Mar Morin M, Rodriguez-Romero R, Rodríguez-García E, Cantón R et al. Prestroke dementia. Cerebrovasc Dis. 2001;11(3):216-24. http://doi.org/10.1159/000047642

14. Klimkowicz A, Dziedzic T, Slowik A, Szczudlik A. Incidence of pre- and poststroke dementia: cracow stroke registry. Dement Geriatr Cogn Disord. 2002;14(3):137-40. http://doi.org/10.1159/000063599

15. Tatemichi TK, Desmond DW, Paik M, Figueroa M, Gropen TI, Stern $Y$ et al. Clinical determinants of dementia related to stroke. Ann Neurol. 1993;33(6):568-75. http://doi.org/10.1002/ana.410330603

16. Jorm AF, Jacomb PA. The Informant Questionnaire on Cognitive Decline in the Elderly (IQCODE): socio-demographic correlates, reliability, validity and some norms. Psychol Med. 1989;19(4):1015-22. http://doi.org/10.1017/S0033291700005742

17. Jorm AF. A short form of the Informant Questionnaire on Cognitive Decline in the Elderly (IQCODE): development and cross-validation. Psychol Med. 1994;24(1):145-53. http://doi.org/10.1017/S003329170002691X

18. Jorm AF. The Informant Questionnaire on cognitive decline in the elderly (IQCODE): a review. Int Psychogeriatr. 2004;16(3):275-93. http://doi.org/10.1017/S1041610204000390

19. Murao K, Leys D, Jacquin A, Kitazono T, Bordet R, Béjot Y et al. Thrombolytic therapy for stroke in patients with preexisting cognitive impairment. Neurology. 2014;82(23):2048-54. http://doi.org/10.1212/WNL.0000000000000493

20. Murao K, Bodenant M, Cordonnier C, Bombois S, Hénon H, Pasquier Fet al. Does pre-existing cognitive impairment no-dementia influence the outcome of patients treated by intravenous thrombolysis for cerebral ischaemia? J Neurol Neurosurg Psychiatry. 2013;84(12):1412-4. http://doi.org/10.1136/jnnp-2013-305281 
21. Cordonnier C, Leys D, Dumont F, Deramecourt V, Bordet R, Pasquier F et al. What are the causes of pre-existing dementia in patients with intracerebral haemorrhages? Brain. 2010;133(11):3281-9. http://doi.org/10.1093/brain/awq246

22. Mounier-Vehier F, Leys D, Rondepierre P, Godefroy O, Pruvo JPP. Silent infarcts in patients with ischemic stroke are related to age and size of the left atrium. Stroke. 1993;24(9):1347-51. http://doi.org/10.1161/01.STR.24.9.1347

23. Debette $S$, Markus HS. The clinical importance of white matter hyperintensities on brain magnetic resonance imaging: systematic review and meta-analysis. BMJ. 2010;341:c3666. http://doi.org/10.1136/bmj.c3666

24. Debette S, Bombois S, Bruandet A, DelbeuckX, Lepoittevin S, Delmaire C et al. Subcortical hyperintensities are associated with cognitive decline in patients with mild cognitive impairment. Stroke. 2007;38(11):2924-30. http://doi.org/10.1161/STROKEAHA.107.488403

25. Bombois S, Debette S, Bruandet A, DelbeuckX, Delmaire C, Leys D et al. Vascular subcortical hyperintensities predict conversion to vascular and mixed dementia in MCl patients. Stroke. 2008;39(7):2046-51. http://doi. org/10.1161/STROKEAHA.107.505206

26. Cordonnier C, Al-Shahi Salman R, Wardlaw J.Spontaneous brain microbleeds: systematic review, subgroup analyses and standards for study design and reporting. Brain. 2007;130(8):1988-2003. http://doi.org/10.1093/brain/awl387

27. Hénon H, Pasquier F, Durieu I, Pruvo JP, Leys D. Medial temporal lobe atrophy in stroke patients: relation to pre-existing dementia.J Neurol Neurosurg Psychiatry. 1998;65(5):641-7. http://doi.org/10.1136/jnnp.65.5.641

28. Chen Y, Wang J, Zhang J, Zhang T, Chen K, Fleisher A et al. Aberrant functional networks connectivity and structural atrophy in silent lacunar infarcts: relationship with cognitive impairments. J Alzheimers Dis. 2014;42(3):841-50. http://doi.org/10.3233/JAD-140948

29. Peters N, Holtmannspötter M, Opherk C, Gschwendtner A, Herzog J, Sämann P et al. Brain volume changes in CADASIL: a serial MRI study in pure subcortical ischemic vascular disease. Neurology. 2006;66(10):1517-22.http://doi.org/10.1212/01.wnl.0000216271.96364.50

30. Jouvent E, Viswanathan A, Mangin JF, O'Sullivan M, Guichard JP, Gschwendtner A et al. Brain atrophy is related to lacunar lesions and tissue microstructural changes in CADASIL. Stroke. 2007;38(6):1786-90. http://doi.org/10.1161/STROKEAHA.106.478263

31. Hénon H, Lebert F, Durieu I, Godefroy O, Lucas C, Pasquier F et al. Confusional state in stroke: relation to preexisting dementia, patient characteristics, and outcome. Stroke. 1999;30(4):773-9. http://doi.org/10.1161/01.STR.30.4.773

32. Hénon H, Durieu I, Lebert F, Pasquier F, Leys D et al. Influence of prestroke dementia on early and delayed mortality in stroke patients.J Neurol. 2003;250(1):10-6. http://doi.org/10.1007/s00415-003-0917-3

33. Verdelho A, Hénon H, Lebert F, Pasquier F, Leys D et al. Depressive symptoms after stroke and relationship with dementia: A three-year follow-up study. Neurology. 2004;62(6):905-11. http://doi.org/10.1212/01.WNL.0000115107.66957.8C

34. Pasquini M, Leys D, Rousseaux M, Pasquier F, Hénon H, Hénon H. Influence of cognitive impairment on the institutionalisation rate 3 years after a stroke.J Neurol Neurosurg Psychiatry. 2007;78(1):56-9. http://doi.org/10.1136/jnnp.2006.102533

35. European Stroke Organisation Executive Committee. Guidelines for management of ischaemic stroke and transient ischaemic attack 2008. Cerebrovasc Dis. 2008;25(5):457-507. http://doi.org/10.1159/000131083

36. Saposnik G, Cote R, Rochon PA, Mamdani M, Liu Y, Raptis S et al. Care and outcomes in patients with ischemic stroke with and without preexisting dementia. Neurology. 2011;77(18):1664-73. http://doi.org/10.1212/WNL.0b013e31823648f1

37. Meretoja A, Putaala J, Tatlisumak T, Atula S, Artto V, Curtze S et al. Off-label thrombolysis is not associated with poor outcome in patients with stroke. Stroke. 2010;41(7):1450-8. http://doi.org/10.1161/STROKEAHA.109.576140
38. Sandercock P, Wardlaw JM, Lindley RI, Dennis M, Cohen G, Murray $\mathrm{G}$ et al. The benefits and harms of intravenous thrombolysis with recombinant tissue plasminogen activator within $6 \mathrm{~h}$ of acute ischaemic stroke (the third international stroke trial [IST-3]): a randomised controlled trial. Lancet. 2012;379(9834):2352-63. http://doi.org/10.1016/S0140-6736(12)60768-5

39. Wardlaw JM, Murray V, Berge E, del Zoppo G, Sandercock P, Lindley RL et al. Recombinant tissue plasminogen activator for acute ischaemic stroke: an updated systematic review and meta-analysis. Lancet. 2012;379(834):2364-72. http://doi.org/10.1016/S0140-6736(12)60738-7

40. Leys D, Cordonnier C. rt-PA for ischaemic stroke: what will the next question be? Lancet. 2012;379(9834):2320-1. http://doi.org/10.1016/S0140-6736(12)60822-8

41. Viswanathan A, Greenberg SM. Cerebral amyloid angiopathy in the elderly. Ann Neurol. 2011;70(6):871-80. http://doi.org/10.1002/ana.22516

42. Wardlaw JM, Smith C, Dichgans M. Mechanisms of sporadic cerebral small vessel disease: insights from neuroimaging. Lancet Neurol. 2013;12(5):483-97. http://doi.org/10.1016/S1474-4422(13)70060-7

43. Whiteley WN, Slot KB, Fernandes P, Sandercock P, Wardlaw J. Risk factors for intracranial hemorrhage in acute ischemic stroke patients treated with recombinant tissue plasminogen activator: a systematic review and metaanalysis of 55 studies. Stroke. 2012;43(11):2904-9. http://doi.org/10.1161/ STROKEAHA.112.665331

44. Fiehler J, Albers GW, Boulanger JM, Derex L, Gass A, Hjort N et al. Bleeding risk analysis in stroke imaging before thromboLysis (BRASIL): pooled analysis of $\mathrm{T} 2{ }^{*}$-weighted magnetic resonance imaging data from 570 patients. Stroke. 2007;38(10):2738-44. http://doi.org/10.1161/STROKEAHA.106.480848

45. Palumbo V, Boulanger JM, Hill MD, Inzitari D, Buchan AM. Leukoaraiosis and intracerebral hemorrhage after thrombolysis in acute stroke. Neurology. 2007;68(13):1020-4. http://doi.org/10.1212/01.wnl.0000257817.29883.48

46. Turc G, Sallem A, Moulin S, Tisserand M, Machet A, Edjlali M et al. Microbleed Status and 3-Month Outcome After Intravenous Thrombolysis in 717 Patients With Acute Ischemic Stroke. Stroke. 2015;46(9):2458-63. http://doi.org/10.1161/STROKEAHA.115.009290

47. Teter B, Ashford JW. Neuroplasticity in Alzheimer's disease.J Neurosci Res. 2002;70(3):402-37. http://doi.org/10.1002/jnr.10441

48. Alshekhlee A, Li CC, Chuang SY, Vora N, Edgell RC, Kitchener JM et al. Does dementia increase risk of thrombolysis? A case-control study. Neurology. 2011;76(18):1575-80. http://doi.org/10.1212/WNL.0b013e3182190d37

49. Busl KM, Nogueira RG, Yoo AJ, Hirsch JA, Schwamm LH, Rost NS. Prestroke dementia is associated with poor outcomes after reperfusion therapy among elderly stroke patients.J Stroke Cerebrovasc Dis. 2013;22(6):718-24. http://doi.org/10.1016/j.jstrokecerebrovasdis.2011.11.005

50. Saposnik G, Kapral MK, Cote R, Rochon PA, Wang J, Raptis S, et al. Is pre-existing dementia an independent predictor of outcome after stroke? A propensity score-matched analysis.J Neurol. 2012;259(11):2366-75. http://doi.org/10.1007/s00415-012-6508-4

51. Arima H, Chalmers J, Woodward M, Anderson C, Rodgers A, Davis S et al. Lower target blood pressures are safe and effective for the prevention of recurrent stroke: the PROGRESS trial.J Hypertens. 2006;24(6):1201-8. http://doi.org/10.1097/01.hjh.0000226212.34055.86

52. McKinney JS, Kostis WJ. Statin therapy and the risk of intracerebral hemorrhage: a meta-analysis of 31 randomized controlled trials. Stroke. 2012;43(8):2149-56. http://doi.org/10.1161/STROKEAHA.112.655894

53. Gallagher AM, Rietbrock S, Plumb J, Staa TP. Initiation and persistence of warfarin or aspirin in patients with chronic atrial fibrillation in general practice: do the appropriate patients receive stroke prophylaxis? J Thromb Haemost. 2008;6(9):1500-6. http://doi.org/10.1111/j.1538-7836.2008.03059.x

54. Flaker GC, Pogue J, Yusuf S, Pfeffer MA, Goldhaber SZ, Granger CB et al. Cognitive function and anticoagulation control in patients with atrial fibrillation. Circ Cardiovasc Qual Outcomes. 2010;3(3):277-83. http://doi.org/10.1161/CIRCOUTCOMES.109.884171 